\title{
Hubungan Status Gizi Ibu Nifas Dengan Produksi ASI
}

\author{
Sri Handayani ${ }^{1)}$, Yopi Suryatim Pratiwi ${ }^{1)}$, Nurul Fatmawati ${ }^{1)}$ \\ Email: srikurniawan87@gmail.com \\ ${ }^{1)}$ Program Studi Kebidanan Jenjang D.3 STIKes Yarsi Mataram
}

\begin{abstract}
ABSTRAK
Angka kematian bayi masih tinggi di Indonesia, 53\% disebabkan oleh faktor nutrisi. ASI eksklusif mampu menurunkan angka kesakitan dan kematian bayi. Produksi ASI kurang merupakan keluhan yang paling sering diutarakan ibu nifas dan menjadi penyebab kegagalan ASI eksklusif. Status gizi pada ibu nifas berpengaruh terhadap produksi ASI. Penelitian ini bertujuan untuk menganalisis hubungan antara status gizi ibu nifas dengan produksi ASI. Penelitian ini merupakan penelitian kuantitatif menggunakan data primer. Sampel dalam penelitian ini adalah seluruh ibu primipara bulan April-Mei 2017 di Puskesmas Gunung Sari, yang memenuhi kriteria inklusi dan eksklusi. Variabel dalam penelitian ini adalah status gizi yang diukur dari LILA dan produksi ASI yang diukur dari volume ASI. Analisis menggunakan uji Mann-Whitney dan T tidak berpasangan. Hasil penelitian menunjukkan tidak ada hubungan antara status gizi dengan produksi ASI baik dilihat hari ke-4 maupun ke-10. Hal ini disebabkan karena isapan bayi merupakan faktor utama yang memengaruhi produksi ASI. Oleh karena itu, ibu nifas dianjurkan untuk menyusui dengan cara yang benar dan setiap dua jam sebagai upaya meningkatkan produksi ASI.
\end{abstract}

Kata kunci: produksi ASI, status gizi

\begin{abstract}
Infant mortality is still high in Indonesia. 53\% is caused by nutritional factors. Exclusive breastfeeding can reduce infant morbidity and mortality. Breastmilk production is less a complaint that is most often expressed by postpartum mothers and is the cause of exclusive breastfeeding failure. Nutritional status of postpartum mothers has an effect on breast milk production. This study aims to analyze the relationship between nutritional status of postpartum mothers and breast milk production. This research is quantitative research using primary data. The sample in this study were all primiparous mothers in April - May 2017 at Gunung Sari Health Center, who met the inclusion and exclusion criteria. The variables in this study were nutritional status measured from LILA and ASI production as measured by breast milk volume. Analysis using the Mann-Whitney and T unpaired tests. The results showed that there was no relationship between nutritional status and ASI production both seen at day 4 and 10 . This is because baby suction is the main factor that influences milk production. Therefore, postpartum mothers are recommended to breastfeed the right way and every two hours in an effort to increase milk production.
\end{abstract}

Keywords: breastmilk production, nutritional status 


\section{A. LATAR BELAKANG}

Angka kematian merupakan salah satu indikator kesehatan yang penting dan mencerminkan derajat kesehatan di suatu wilayah. Angka Kematian Bayi (AKB) di Indonesia periode 2007-2012 sebesar 32 per 1.000 kelahiran hidup, Angka Kematian Neonatal (AKN) sebesar 19 per 1.000 kelahiran hidup, dan Angka Kematian Balita (AKABA) sebesar 40 per 1.000 kelahiran hidup.[1] Komitmen global dalam Millennium Development Goals (MDGs) pada tujuan ke-4 menetapkan target terkait kematian anak, yaitu menurunkan AKB menjadi 23 per 1000 kelahiran hidup dan AKABA menjadi 32 per 1000 kelahiran hidup atau menurunkan angka kematian hingga dua per tiga dalam kurun waktu 1990-2015.[2]

Angka kematian bayi di Indonesia sebagian besar terkait dengan faktor nutrisi, yaitu sebesar 53\%. Beberapa penyakit yang timbul akibat malnutrisi antara lain pneumonia $(20 \%)$, diare $(15 \%)$, dan perinatal (23\%). Statistik juga menunjukkan lebih dari 70\% kematian Bayi lima tahun (Balita) disebabkan diare, pneumonia, campak, malaria, dan malnutrisi.[3]

Air Susu Ibu (ASI) eksklusif mampu menurunkan angka kesakitan dan kematian bayi.[4] Pemberian ASI secara optimal dapat mencegah 1,4 juta kematian di seluruh dunia pada Balita setiap tahun dan mengurangi kematian karena infeksi pernapasan akut dan diare 50-95\%.[5] Menyusui suboptimal menyebabkan $45 \%$ kematian neonatal karena infeksi menular, $30 \%$ kematian karena diare, dan $18 \%$ kematian karena gangguan pernapasan akut pada anak di bawah usia lima tahun di negara berkembang.[6]

ASI eksklusif adalah pemberian makan pada bayi dengan ASI saja dan tidak ada makanan tambahan, air, atau cairan lain (kecuali obat-obatan dan vitamin, jika diperlukan) selama enam bulan pertama kehidupan. ASI adalah makanan terbaik bagi bayi dan memiliki keseimbangan nutrisi yang tepat, tersedia secara biologis, mudah dicerna, melindungi bayi dari penyakit, dan memiliki sifat antiinflamasi.[7]

Capaian pemberian ASI eksklusif di Indonesia masih jauh dari target nasional sebesar $80 \%$. Persentase pemberian ASI eksklusif pada bayi 0-6 bulan di Indonesia pada tahun 2013 sebesar 54,3\%. Persentase pemberian ASI eksklusif tertinggi terdapat di Nusa Tenggara Barat (NTB) sebesar $79,74 \%$ dan terendah di Provinsi Maluku sebesar 25,21\%.[3]

Produksi ASI yang kurang merupakan keluhan yang sering diutarakan oleh ibu terutama minggu pertama nifas dan menjadi penyebab kegagalan ASI eksklusif. Penelitian di Australia menyebutkan dari 556 ibu melahirkan, 29\% berhenti menyusui bayinya pada minggu kedua dengan alasan ASI kurang.[8] Hasil wawancara pada penelitian yang dilaksanakan di Rumah Sakit Bersalin (RSB) Kabupaten Sleman Yogyakarta terhadap 48 responden, 31,25\% ibu menyatakan mengalami ASI kurang.[9]

Prevalensi risiko Kekurangan Energi Kronis (KEK) wanita hamil umur 15-49 tahun, secara nasional sebanyak 24,2 persen. Prevalensi risiko KEK terendah di Bali $(10,1 \%)$ dan tertinggi di Nusa Tenggara Timur $(45,5 \%)$. Penilaian KEK dapat dinilai dengan pengukuran Lingkar Lengan Atas (LILA), dimana LILA dapat digunakan untuk menilai status gizi ibu nifas.[10]

Penelitian Irawati, di Indonesia menunjukkan bahwa status gizi ibu pada masa laktasi berpengaruh terhadap keberhasilan menyusui, ibu yang kurang gizi berisiko tidak berhasil menyusui 2,26- 
2,56 kali lebih besar dibandingkan ibu dengan gizi baik. Ibu hamil dengan kenaikan BB lebih rendah dari BB yang direkomendasikan mempunyai cadangan lemak rendah. Hal ini secara negatif akan memengaruhi kemampuan ibu memproduksi ASI.[11]

Berdasarkan latar belakang di atas, peneliti tertarik melakukan penelitian dengan judul "Hubungan Status Gizi Ibu Nifas dengan Produksi ASI".

\section{B. METODE PENELITIAN}

\section{Desain Penelitian}

Penelitian ini merupakan penelitian kuantitatif menggunakan data primer. Penelitian ini menggunakan metode kuantitatif karena fokus dari penelitian ini adalah untuk mengetahui angka dari LILA pada ibu masa nifas dengan produksi ASI.

\section{Populasi dan Sampel Penelitian}

Populasi dalam penelitian ini adalah ibu primipara di bulan April-Mei 2017 di Puskesmas Gunung Sari. Sampel dalam penelitian ini adalah seluruh ibu primipara di bulan April-Mei 2017 di Puskesmas Gunung Sari, yang memenuhi kriteria sampel. Kriteria inklusi dalam penelitian ini adalah Ibu primipara hari pertama, melahirkan bayi aterm, tunggal, dan sehat, berat badan lahir bayi $\geq 2500$ gram, dan bersedia menjadi responden. Kriteria eksklusi dalam penelitian ini adalah Ibu yang memiliki masalah pada payudara, yaitu puting datar/tenggelam dan riwayat operasi pada payudara, Ibu dan atau bayi yang mengalami komplikasi berat dan memerlukan perawatan, dan bayi yang mengalami kelainan kongenital.

\section{Variabel Penelitian}

Variabel bebas dalam penelitian ini adalah status gizi yang dilihat dari hasil pengukuran LILA dan variabel terikat dalam penelitian ini adalah produksi ASI yang dilihat dari volume ASI.

\section{Waktu dan Lokasi Penelitian}

Penelitian ini dilakukan bulan April-Mei

2017 di Puskesmas Gunung Sari

\section{Metode Pengumpulan dan \\ Pengolahan Data}

Data yang dikumpulkan dalam penelitian ini adalah data primer, yaitu data tentang status gizi dan produksi ASI. Status gizi dinilai berdasarkan pengukuran LILA, segera setelah ibu melahirkan. Pengukuran volume ASI dilakukan setiap pagi hari (pukul 06.00-12.00 WIB), sebanyak dua kali, yaitu hari ke-4 dan ke-10, sebelum bayi menyusu atau 2-3 jam setelah bayi menyusu guna mengembalikan produksi ASI pada volume sebelum disusukan ke bayinya. Hasil memompa diukur menggunakan botol bayi dalam satuan $\mathrm{ml}$. Variabel umur akan dinilai segera setelah bayi lahir atau sebelum ibu meninggalkan Puskesmas.

Analisis data dilakukan untuk mengetahui perbedaan rata-rata volume ASI antara responden dengan LILA $<23,5$ $\mathrm{cm}$ (berisiko) dan $\geq 23,5 \mathrm{~cm}$ (tidak berisiko).

Pengolahan data pada penelitian ini dilakukan dengan menggunakan paket program SPSS meliputi analisis deskriptif (analisis univariat) dan bivariat. Sebelum dilakukan analisis, terlebih dahulu dilakukan uji normalitas data pada data berskala numerik (volume ASI hari ke-4 dan ke-10) untuk mengetahui apakah data berdistribusi normal atau tidak. Uji normalitas data yang digunakan adalah uji Shapiro-Wilk karena jumah sampel $\leq 50$, dimana hasil uji normalitas volume ASI hari ke-4 diperoleh hasil $\mathrm{p}<0,05$ yang artinya data berdistribusi tidak normal dan volume ASI hari ke-10 diperoleh hasil p>0.05 yang artinya data berdistribusi normal. Oleh karena itu, uji nonparametrik digunakan untuk menguji hubungan status gizi dengan produksi ASI hari ke-4, yaitu uji Mann-Whitney, sedangkan uji parametrik digunakan untuk menguji 
hubungan status gizi dengan produksi ASI hari ke-10, yaitu uji T tidak berpasangan.

\section{Etika Penelitian}

Penelitian ini berupaya memegang teguh sikap ilmiah dan etika dalam penelitian serta berusaha meminimalkan kerugian yang mungkin timbul dan memaksimalkan penelitian.

\section{HASIL DAN PEMBAHASAN}

\section{Hasil Penelitian}

Penelitian dengan judul "Hubungan Status Gizi Ibu Nifas dengan Produksi ASI", diperoleh hasil sebagai berikut:

Tabel 1. Distribusi Frekuensi Responden Berdasarkan Status Gizi Ibu Nifas

\begin{tabular}{|c|l|c|c|}
\hline No. & Status Gizi (LILA) & N & \% \\
\hline 1 & Berisiko KEK & 11 & 24,4 \\
\hline 2 & Tidak Berisiko KEK & 34 & 75,6 \\
\hline
\end{tabular}

Berdasarkan tabel di atas, sebagian besar responden $(75,6 \%)$ tidak berisiko KEK.

Tabel 2. Median dan Rerata Volume ASI Hari ke-4 dan ke-10

\begin{tabular}{|c|c|c|}
\hline No. & Volume ASI & Hasil \\
\hline 1. & $\begin{array}{l}\text { Volume ASI Hari Ke-4 } \\
\text { Median (Minimum- } \\
\text { Maksimum) }\end{array}$ & $72(15-336)$ \\
\hline 2. & $\begin{array}{l}\text { Volume ASI Hari Ke- } \\
10 \\
\text { Rerata (S.B) } \\
\text { IK 95\% }\end{array}$ & $\begin{array}{l}114,62(67,71) \\
94,28-134,97\end{array}$ \\
\hline
\end{tabular}

Berdasarkan tabel di atas, median data volume ASI hari ke-4 $72 \mathrm{ml}$ dan rerata volume ASI hari ke-10 114,62 ml.

Hasil analisa statistik dengan uji Mann Whitney pada tingkat kepercayaan 95\% antara LILA dengan produksi ASI hari ke4 menunjukkan hubungan yang tidak bermakna $(p=0,579)$. Jadi tidak ada hubungan antara LILA dengan produksi ASI hari ke-4.

Hasil analisa statistik dengan uji T tidak berpasangan pada tingkat kepercayaan $95 \%$ antara LILA dengan produksi ASI hari ke10 menunjukkan hubungan yang tidak bermakna $(\mathrm{p}=0,375)$. Jadi, tidak ada hubungan antara LILA dengan produksi ASI hari ke-10.

\section{Diskusi}

Variabel dalam penelitian ini adalah status gizi yang diukur dari LILA dan produksi ASI yang diukur dari volume ASI.

LILA adalah ukuran lingkar lengan atas responden yang diukur dengan pita ukur dari Depkes dengan kriteria Tidak berisiko KEK bila hasil pengkuran LILA $<23,5 \mathrm{~cm}$ dan berisiko KEK bila $\geq 23,5 \mathrm{~cm}$. Pengukuran LILA pada kelompok wanita usia subur (WUS) adalah salah satu cara deteksi dini yang mudah dan dapat dilaksanakan oleh masyarakat umum untuk mengetahui status gizi, kelompok berisiko kekurangan energi kronis (KEK). Pengukuran LILA merupakan salah satu pilihan untuk penentuan status gizi karena mudah dilakukan dan tidak memerlukan alat-alat yang sulit diperoleh serta harganya murah.[12].

Pengukuran volume ASI dilakukan hari ke-4 dan ke-10. Pengukuran hari ke-4 disebabkan hormon progesteron menurun 10 kali lipat pada 4 hari masa nifas.[13] Kadar prolaktin ibu menyusui turun sekitar 50 persen pada minggu pertama postpartum.[14] Hal ini memungkinkan kadar prolaktin yang memang sudah tinggi pada akhir kehamilan memulai produksi ASI.[15]

Pengukuran volume ASI hari ke-10 disebabkan puncak kadar prolaktin wanita pada 10 hari postpartum, dengan produksi ASI yang normal rata-rata $90 \mathrm{ng} / \mathrm{ml}$, [14],[15] sedangkan pada wanita dengan produksi ASI kurang rata-rata 46 $\mathrm{ng} / \mathrm{ml} .[16]$

Hasil analisa statistik antara LILA dengan produksi ASI hari ke-4 dan ke-10 menunjukkan tidak ada hubungan antara status gizi dengan produksi ASI. Hasil penelitian ini sejalan dengan penelitian lain dimana hasil analisa statistik dengan uji Mann Whitney pada tingkat kepercayaan 
95\% antara LILA dengan kecukupan ASI menunjukkan hubungan yang tidak bermakna $(\mathrm{p}=0,319)$. Menurut Johannes (2005) menemukan bahwa tidak ada pengaruh antara status gizi ibu menyusui (LILA) terhadap eksklusifitas menyusui.[17]

Hal ini disebabkan sebagian besar responden tidak berisiko KEK karena pengukuran LILA hanya ada 2 kategori sehingga responden yang mengalami kegemukan dan berat badan normal masuk dalam kategori tidak berisiko KEK.

Hal ini juga dipengaruhi oleh usia kehamilan semua responden yakni $\geq 9$ bulan $(100 \%)$. Usia kehamilan yang normal berdampak pada berat badan lahir bayi, sehingga berpengaruh juga pada kekuatan menghisap bayi pada saat menyusu. Penelitian menunjukkn ada hubungan berat bayi saat lahir dengan volume ASI. Hal ini berkaitan dengan kekuatan untuk menghisap, frekuensi, dan lama penyusuan yang baik pada bayi dengan berat badan lahir normal. Berat bayi sangat erat berhubungan dengan kekuatan menghisap saat menyusu.[18]

Isapan bayi pada saat menyusu merangsang puting susu dan areola payudara dimana akan merangsang ujungujung saraf sensoris yang berfungsi sebagai reseptor mekanik. Rangsangan ini dilanjutkan ke hipotalamus melalui medula spinalis dan mesensephalon, dan menyebabkan lonjakan sekresi prolaktin sebesar 10-20 kali lipat yang berlangsung kira-kira 1 jam. Hipotalamus akan menekan pengeluaran faktor yang menghambat sekresi prolaktin dan sebaliknya merangsang pengeluaran faktor yang memacu sekresi prolaktin.[19] Faktor yang memacu sekresi prolaktin akan merangsang hipofisis anterior sehingga melepaskan prolaktin. Hormon ini merangsang sel-sel epitelial alveolar yang berfungsi untuk sekresi dan sintesis air susu.[20]
Prolaktin menyebabkan dimulainya laktogenesis karena mengikat reseptor khusus pada permukaan membran sel epitel payudara. Reseptor ini terdiri dari domain eksternal dan internal. Prolaktin mengaktifkan reseptor secara berurutan melalui penggabungan dua molekul yang identik (homodimerisasi), yang menyebabkan aktivasi Janus Kinasus 2 (JAK2) terkait dengan domain kinase sitoplasma. JAK2 merangsang Signal Transducer and Activator of Transcription (STAT 5) sehingga menyebabkan proliferasi sel epitalium alveolus.[21] Di samping prolaktin, Epidermal Growth Factor (EGF) juga berperan dalam proliferasi sel.[22] Prolaktin juga merangsang beberapa asam amino untuk sintesis protein susu (kasein dan $\alpha$ laktalbumin) dan sintesis gula laktosa sebagai lemak susu.[23]

Kadar prolaktin dalam darah distimulasi oleh Prolactin Releasing Hormon (PRH) dan kadarnya diturunkan oleh Prolactin Inhibiting Hormon (PIH), dopamin, dan peningkatan prolaktin dalam darah. PIH mampu menurunkan kadar prolaktin hingga 10 kali lipat.[24] Dopamin memainkan peran dominan dalam regulasi sekresi prolaktin. Melalui efek langsung pada sel laktotrop hipofisis anterior, dopamin menghambat basally highsecretory tone dari sel. Pengahambatan ini diakhiri dengan mengikat reseptor dopamine 2 (D2) yang diekspresikan pada membran sel laktotrop, yang menghasilkan sebuah penurunan eksositosis prolaktin dan menghambat sinyal cyclic Adenosine Monophosphate/Protein Kinase A (cAMP/PKA) oleh adenilat siklase.[25]

Phosphodiesterase (PDE), enzim yang mendegradasi cAMP dan mengatur kembali sinyal cAMP/PKA, mengontrol sinyal dopaminergik pada kedua saraf, yaitu neuron striatopallidal dan striatonigral. PDE10A terutama mengatur Dopamine and 
Cyclic Adenosiene 3'5'-monophosphateregulated-phosphoprotein $32 \mathrm{kDa}$ (DARPP-32) fosforilasi sehingga menghambat phosphotase 1 (PP-1) dan memengaruhi sinyal dopaminergik.[26,27] Peningkatan kadar serum prolaktin meningkatkan sintesis dopamin oleh hipotalamus dan konsentrasi dopamin pada portal hipotalamus-hipofisis darah.[28]

Kadar prolaktin wanita pada 10 hari postpartum dengan produksi ASI yang normal rata-rata $90 \mathrm{ng} / \mathrm{ml},[29,30]$ sedangkan pada wanita dengan produksi ASI kurang rata-rata $46 \mathrm{ng} / \mathrm{ml}$.[31] Setelah itu, menurun perlahan, tetapi tetap meningkat sampai 180 hari postpartum (44,3 ng/ml). Puncak konsentrasi prolaktin tertinggi kira-kira 45 menit setelah awal sesi menyusui kemudian kembali ke level sebelum rangsangan tiga jam kemudian.[32] Konsentrasi prolaktin tertinggi selama menyusui terdapat pada malam hari, dan terendah pada pagi hari, karena mengikuti ritme sikardian.[29] Wanita amenorea mempunyai tingkat prolaktin yang lebih tinggi (kira-kira 110 $\mathrm{ng} / \mathrm{ml}$ ) dibandingkan wanita yang menstruasi sebelum 180 hari (kira-kira 70,1 $\mathrm{ng} / \mathrm{ml}$ ).[33] Jika lonjakan prolaktin tidak ada atau diblokir sebagai akibat dari kerusakan hipotalamus atau hipofisis, atau bila laktasi tidak dilakukan terus menerus payudara kehilangan kemampuan untuk menghasilkan susu dalam waktu 1 minggu atau lebih,[30] tetapi produksi susu dapat terus untuk beberapa tahun jika anak terus mengisap, meskipun laju pembentukan susu biasanya menurun jauh setelah 7-9 bulan.[34]

Bersamaan dengan pembentukan prolaktin oleh adenohipofise, rangsangan yang berasal dari isapan bayi ada yang dilanjutkan ke neurohipofisis (hipofisis posterior) yang kemudian dikeluarkan oksitosin.[19] Oksitosin dilepaskan dari terminal neurosecretory di neurohipofisis menuju sirkulasi sistemik setelah stimulasi neuron magnoselular yang terletak didua inti hipotalamus, yaitu paraventricular nuclei (PVN) dan supraoptic nuclei (SON).[35] Reseptor oksitosin dikodekan 389-asam amino polipeptida dengan tujuh domain transmembran. Selain pada SON dan PVN, reseptor oksitosin juga ditemukan di daerah korteks, hipokampus, sistem limbik, ganglia basalis, medial preoptic area (MPOA), bulbus olfaktori, amigdala, dan batang otak.[36]

Saraf pusat histaminergik terlibat dalam kontrol sekresi oksitosin dalam berbagai kondisi fisiologis termasuk pada masa nifas dan menyusui. Konsentrasi yang tinggi dari reseptor histamine (H1) diidentifikasi dalam PVN dan SON. Histamin dalam PVN meningkatkan pelepasan oksitosin baik sistemik dan intranuklear. Peningkatan ini tergantung pada stimulasi reseptor histamin $\mathrm{H} 1$ dan $\mathrm{H} 2$ dan aktivasi dari reseptor $\alpha$-noradrenergik. Histamin merangsang pelepasan oksitosin dengan merangsang pelepasan norepinefrin. Oleh karen itu, penghambatan sintesis histamin atau pemberian antagonis reseptor $\mathrm{H} 1$ atau antagonis reseptor $\mathrm{H} 2$ atau antagonis adrenergik phentolamine akan mencegah pelepasan oksitosin karena isapan bayi.[37]

Oksitosin yang dilepaskan ke sirkulasi sistemik diangkut melalui aliran darah menuju uterus yang dapat menimbulkan kontraksi pada uterus sehingga terjadi involusi dari organ tersebut.[20] Oksitosin yang sampai pada alveoli akan memengaruhi sel mioepitalium dan menyebabkan kontraksi. Kontraksi dari sel akan memeras air susu yang telah disintesis keluar dari alveoli dan masuk ke sistem duktulus. Hal ini menyebabkan peningkatan tekanan intraduktal, terjadinya pelebaran duktus, dan akibatnya terjadi peningkatan laju aliran air susu melalui duktus laktiferus masuk ke mulut bayi. 
Dalam waktu 30 detik sampai 1 menit setelah bayi mengisap payudara air susu mulai mengalir. Proses ini dikenal sebagai reflek let-down atau pengeluaran air susu.[38]

\section{KESIMPULAN}

Hasil analisis antara status gizi dan produksi ASI menunjukkan tidak ada hubungan antara status gizi dan produksi ASI. Hal ini disebabkan sebagian besar responden tidak berisiko KEK karena pengukuran LILA hanya ada 2 kategori sehingga responden yang mengalami kegemukan dan berat badan normal masuk dalam kategori tidak berisiko KEK. Hal ini juga dipengaruhi oleh usia kehamilan semua responden yakni $\geq 9$ bulan $(100 \%)$. Usia kehamilan yang normal berdampak pada berat badan lahir bayi, sehingga berpengaruh juga pada kekuatan menghisap bayi pada saat menyusu. Oleh karena itu, ibu nifas dianjurkan untuk menyusui dengan cara yang benar dan setiap dua jam sebagai upaya meningkatkan produksi ASI.

\section{E. UCAPAN TERIMA KASIH}

Ucapan terima kasih kami sampaikan kepada responden yang telah membantu dalam penelitian dan staf Puskesmas Gunung Sari atas bantuan dan kerjasamanya yang sangat baik kepada kami selama penelitian.

\section{DAFTAR PUSTAKA}

[1] Kementerian Kesehat RI. Survei Demografi dan Kesehatan Indonesia (SDKI) 2012. Jakarta: Badan Penelitian dan Pengembangan Kesehatan Kementerian RI. 2012.

[2] Badan Perencanaan Pembangunan Nasional. Laporan Pencapaian Tujuan Pembangunan Millenium di Indonesia. ISBN 978-979-3764-64-1, 2011.
[3] Kementerian Kesehatan RI. Profil Kesehatan Indonesia 2013. Jakarta: Kementerian Kesehatan Republik Indonesia. 2014.

[4] Mihrshahi S, Oddy WH, Peat JK, Kabir I. Association between infant feeding patterns and diarrhoeal and respiratory illness: a cohort study in Chittagong, Bangladesh. Int Breastfeed J. 2008;3(1):23-8.

[5] UNICEF. Improving Exclusive Breast Feeding Practices by using Communication for Development in Infant and young Child Feeding Programs. 2010.

[6] World Health Organization. Global health risks: mortality and burden of disease attributable to selected major risks: World Health Organization; 2009.

[7] Mekuria G, Edris M. Exclusive breastfeeding and associated factors among mothers in Debre Markos, Northwest Ethiopia: a cross-sectional study. International breastfeeding journal. 2015;10(1):1-7.

[8] Scott J, Colin W. Breastfeeding: reasons for starting, reasons for stopping and problems along the way. Breastfeeding Review. 2002;10(2):13.

[9] Sa'roni, Sadjiman T, Sja'bani M, Zulaela Z. Effectiveness of the Sauropus androgynus (1.) Merr leaf extract in increasing mother's breast milk production. Media Penelitian dan Pengembangan Kesehatan. 2004;14(3 Sept).

[10] Badan Penelitian dan Pengembangan Kesehatan Kemenks RI. Riset Kesehatan Dasar 2013. Kemenkes RI: 2013

[11] Irawati A, Triwinarto A, Salimar S, Raswanti I. Pengaruh status gizi ibu selama kehamilan dan menyusui terhadap keberhasilan pemberian air susu ibu. Penelitian Gizi dan Makanan 
(The Journal of Nutrition and Food Research). 2003;26(2).

[12] Supariasa, I.D.N. 2002. Penilaian Status Gizi. Jakarta: EGC.

[13] Corwin, EJ. Buku Saku Patofisiologi (Handbook of pathophysiologi). Jakarta: EGC; 2001.

[14] Tyson J, Hwang P, Guyda H, Friesen H. Studies of prolactin secretion in human pregnancy. Am J Obstet Gynecol. 1972;113(1):14-20.

[15] Riordan J, Wambach K. Breastfeeding and human lactation: Jones \& Bartlett Learning; 2005.

[16] Anderson PO, Valdés V. A critical review of pharmaceutical galactagogues. Breastfeeding Medicine. 2007;2(4):229-42.

[17] Pujiastuti, N. Korelasi Antara Status Gizi Ibu Menyusui Dengan Kecukupan Asi Di Posyandu Desa Karang Kedawang Kecamatan Sooko Kabupaten Mojokerto. Jurnal Keperawatan, ISSN: 2086-3071

[18] Haryono R dan Setianingsih S. 2014. Manfaat ASI Eksklusif Untuk Buah Hati Anda. Yogyakarta: Gosyen Publishing.

[19] Soetjiningsih. Seri Gizi Klinik ASI Petunjuk untuk Tenaga Kesehatan. Jakarta: EGC; 1997.

[20] Corwin, EJ. Buku Saku Patofisiologi (Handbook of pathophysiologi). Jakarta: EGC; 2001.

[21] Bachelot A, Binart N. Reproductive role of prolactin. Reproduction. 2007;133(2):361-9.

[22] Penagos Tabares F, Bedoya Jaramillo JV, Ruiz-Cortés ZT. Pharmacological overview of galactogogues. Veterinary medicine international. 2014;2014.

[23] Freeman ME, Kanyicska B, Lerant A, Nagy G. Prolactin: structure, function, and regulation of secretion.
Physiological

reviews. 2000;80(4):1523-631.

[24] Waugh A, Grant A. Ross \& Wilson anatomy and physiology in health and illness: Elsevier Health Sciences; 2014.

[25] Fitzgerald P, Dinan TG. Prolactin and dopamine: what is the connection? A review article. Journal of Psychopharmacology. 2008;22(2 suppl):12-9.

[26] Nishi A, Kuroiwa M, Miller DB, O'Callaghan JP, Bateup HS, Shuto T, et al. Distinct roles of PDE4 and PDE10A in the regulation of cAMP/PKA signaling in the striatum. The Journal of Neuroscience. 2008;28(42):10460-71.

[27] Nishi A, Kuroiwa M, Shuto T. Mechanisms for the modulation of dopamine D1 receptor signaling in striatal neurons. Frontiers in neuroanatomy. 2011;5.

[28] Freeman ME, Kanyicska B, Lerant A, Nagy G. Prolactin: structure, function, and regulation of secretion. Physiological reviews. 2000;80(4):1523-631.

[29] Riordan J, Wambach K. Breastfeeding and human lactation: Jones \& Bartlett Learning; 2005.

[30] Tyson J, Hwang P, Guyda H, Friesen H. Studies of prolactin secretion in human pregnancy. Am $\mathbf{J}$ Obstet Gynecol. 1972;113(1):14-20.

[31] Anderson PO, Valdés V. A critical review of pharmaceutical galactagogues. Breastfeeding Medicine. 2007;2(4):229-42.

[32] Noel GL, Suh HK, Frantz AG. Prolactin Release During Nursing and Breast Stimulation in Postpartum and Nonpostpartum Subjects 1. The Journal of Clinical Endocrinology \& Metabolism. 1974;38(3):413-23.

[33] Battin DA, Marrs RP, Fleiss PM, Mishell JR. Effect of suckling on serum prolactin, luteinizing hormone, follicle- 
stimulating hormone, and estradiol during prolonged lactation. Obstetrics \& Gynecology. 1985;65(6):785-8.

[34] Guyton AC, Hall JE. Texbook of medical physiology. Elsevier; 2006.

[35] Bealer SL, Crowley WR. Stimulation of Central and Systemic Oxytocin Release by Histamine in the Paraventricular Hypothalamic Nucleus: Evidence for an Interaction with Norepinephrine 1. Endocrinology. 1999;140(3):1158-64.

[36] Baskerville TA, Douglas AJ. Dopamine and oxytocin interactions underlying behaviors: potential contributions to behavioral disorders. CNS neuroscience \& therapeutics. 2010;16(3):e92-e123.

[37] Vacher CM, Frétier P, Créminon C, Calas A, Hardin-Pouzet H. Activation by serotonin and noradrenaline of vasopressin and oxytocin expression in the mouse paraventricular and supraoptic nuclei. The Journal of neuroscience. 2002;22(5):1513-22.

[38] Geddes DT. Inside the lactating breast: the latest anatomy research. Journal of Midwifery \& Women's Health. 2007;52(6):556-63. 